\title{
A study on the sustainable management framework and the economic value evaluation for Taiwan Reservoir Watershed
}

\author{
SHIH-CHUNG LU ${ }^{1}$, SZU-HSIEN PENG ${ }^{2}$, HWONG-WEN MA ${ }^{3}$ \\ ${ }^{1}$ Department of Architecture and Interior Design, National Taiwan University, Taiwan \\ ${ }^{2}$ Department of Architecture and Interior Design, Chienkuo Techology University, Taiwan \\ ${ }^{3}$ Graduate Institute of Environmental Engineering, National Taiwan University, Taiwan
}

\begin{abstract}
A study on the sustainable management framework and the economic value evaluation for Taiwan Reservoir Watershed. Recently lack of sustainable management for the reservoir watershed becomes a predicament for the water issues in Taiwan. The study tried to recognize the framework of the sustainable management of the Taiwan reservoir watershed and its key factors by using the analytic hierarchy process and the Delphi method. Through the identification questionnaires and the CVM (contingent valuation method), it also discussed the gap of expert and public for the identification of satisfaction, environmental protection and the potential value for the recent reservoir watershed. However, the results showed that the "natural stability" is the significant factor in the first level and the "Nature resources conservation" and "Water storage amount" are the most important factors for the detailed level. In addition, the expert opinions were not proved by public identification, and the present governance budgets are too low to respond to the potential values of public expectancy.
\end{abstract}

Key words: reservoir watershed, sustainable management; Taiwan reservoir, analytic hierarchy process (AHP), contingent valuation method (CVM).

\section{INTRODUCTION}

The area of reservoir watershed occupies nearly one seventh of Taiwan, but few reservoirs would own the suitable development management model to solve the practical problems. Due to the recently coming of flood and drought disasters, it is necessary that the water resource development should have more comprehensive plan and problem introspection. Obviously, the sustainable development of water resource cannot be only dependent on the establishment of reservoirs. It would be better to improve the existed reservoir though the establishment of assessing model.

Although there are a lot of hazards happening, the governance for the water resources in Taiwan seems not to be able to solve the issues and it also can not offer a suitable strategy framework toward sustainability. In addition, the Taiwan government offers a lot of costs and resources to protect the reservoir watershed, but the public identification cannot understand the policy and the practical works after the hazards. The situation shows that there is a large gap between public and the authorities, and the public identification plays a very important role in improving the environmental issues. The gap may produce more problems inhibit the policy action and the decision-making. Therefore, the study tried 
to recognize the framework of the sustainable management of the Taiwan reservoir watershed and its key factors by using the analytic hierarchy process and the Delphi method. Through the identification questionnaires and the CVM (contingent valuation method), it also discussed the gap between expert and public for identification of satisfaction, environmental protection and the potential value for the recent reservoir watershed.

\section{MATERIAL AND METHODS}

\section{Analytic Hierarchy Process}

\section{The understanding of AHP}

The Analytic Hierarchy Process (AHP) is a structured technique for dealing with complex decisions. Rather than prescribing a "correct" decision, the AHP helps the decision makers to find the one that best suits their needs and their understanding of the problem. Based on mathematics and psychology, it was developed by Thomas L. Saaty in the 1970s and has been extensively studied and refined since then. The AHP provides a comprehensive and rational framework for structuring a decision problem, for representing and quantifying its elements, for relating those elements to overall goals, and for evaluating alternative solutions. It is used around the world in a wide variety of decision situations, in fields such as government, business, industry, healthcare, and education (Millet, Harker 1990; Chang et al. 1995).

\section{Instrument of $A H P$}

The study makes sure the relative relationship among the influence factors by using literature review and pre-research, and it also confirms the inter-relationship and framework of sustainable Taiwan reservoir watershed by using the expert

TABLE 1. The framework of sustainable Taiwan reservoir

\begin{tabular}{|c|c|c|c|}
\hline Goal & Lv.1 & Lv.2 & Lv.3 \\
\hline \multirow{17}{*}{ 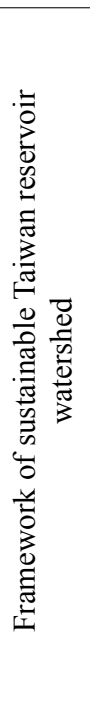 } & \multirow{5}{*}{ ecological steadiness } & \multirow{3}{*}{ Eco-resources } & Forestry \\
\hline & & & Agriculture \\
\hline & & & Biodiversity \\
\hline & & \multirow{2}{*}{ Human behaviors } & Agriculture pollution \\
\hline & & & Recreation pollution \\
\hline & \multirow{4}{*}{ economic suitability } & \multirow{2}{*}{ Water quality } & River pollution standard \\
\hline & & & Eutrophication \\
\hline & & \multirow{2}{*}{ Water amount } & Acceptable capacity \\
\hline & & & Accumulation rate \\
\hline & \multirow{8}{*}{ social acceptability } & \multirow{5}{*}{ Social economy } & Population \\
\hline & & & Transportation \\
\hline & & & Education and training \\
\hline & & & Land use \\
\hline & & & Cultural resources \\
\hline & & \multirow{3}{*}{ Local development } & Public identification \\
\hline & & & Main development content \\
\hline & & & Local industry \\
\hline
\end{tabular}


questionnaires and in-depth interview. The factors in the framework are three-level, and the first level includes three parts: ecological steadiness, economic suitability, and social acceptability. Then, the factors in the other two levels can be seen in Table 1. Meanwhile, the related experts were chosen, and the amount of the experts for the questionnaires is 22 (including 12 scholars and 10 government members), and the background are wide to cover the different fields in the issues. Through the two-step expert questionnaires, the relative weight has been accounted by using the software, Expert Choice, and the results could be put on the framework to assess the potential sustainable strategies.

\section{Contingent Valuation Method}

\section{The understanding of CVM}

The comprehensive perception of themed restaurants is abstractive and not means for transaction. For the valuation of those kinds of none-market resources, Ciriacy-Wantrup (1947) first proposed the Contingent Valuation Method (CVM) as a survey-based economic technique. This method offers an imaginative pricing system to trace the demand curve for a public good unavailable from market data (Hanemann 1994). This system referred to as a preference model helps us recognize what are worth to people (Schelling 1968). Portney (1994) argued that the approach of CVM must first "contain a scenario or description of the (hypothetical or real) policy or program for the respondents to value or vote upon." Second, "the survey must contain a mechanism for eliciting value or a choice from the respondents" (pp. 5-6), typically with open-ended questions such as how much money people would be willing to pay for...? Two guidelines for the application of CVM are that personal interviews, rather than telephone interviews, should be conducted to improve face validity, and follow-up questions should be asked to ensure that respondents understand the choices they are being asked to make and to discover the reasons for their answers. These two guidelines were followed in this study. CVM is now used in research throughout the world in a variety of fields, including transportation, sanitation, health, the arts, education and environmental studies (Carson, Martin, Wright 1994). For general respondents, CVM offers a simple way for them to express their degrees of preference.

\section{Instrument of CVM}

The questionnaire of CVM used in this study measured a 22-item group for "Evaluation of the satisfaction for the Taiwan reservoir watershed", one four-item-group for "Willingness to Pay and Follow-up Questions," and a seven-item group for "Demographic Attributes." The items "Willingness to pay," "Age" and "Annual Income" were set to be open-ended as interval measures. They were interviewed through the qualitative process and acted as the "subject matter expert rater" to check every item of the questionnaire in a yes-or-no referendum format. Each qualified item was approved by more than half of the panelists. To make sure the survey was clear and understandable; it was given as a pilot study to 100 visitors who had been traveling around one of the Taiwan reservoir watersheds. The reliability and 
internal consistency of the survey were assessed by using Cronbach's coefficient alpha.

\section{Sampling}

The survey was conducted in August, 2009, through 500 questionnaires using five-point Likert-type scale designed to identify respondents' preferences regarding the Taiwan reservoir watershed. Interviewers had been trained previously and were ready to administer the surveys. Survey participants were interviewed through a convenient sampling approach in urban areas of Taiwan's four main regions - northern, central, southern, and eastern - with sample sizes conforming to the population ratio of each region. Respondents were asked to complete every item in the questionnaire. A total of 47 respondents stated that they didn't have time to finish the survey or refused to complete it, and 36 stated that they had never been to themed restaurants, leaving a qualified sample size of 417 , or a response rate of $83.4 \%$. T-test and ANOVA tests were used to identify the differentiation of different groups. Principle component analysis, the contingent valuation method, and general linear regression analysis with the stepwise method were used to analyze the effects of the principle factors and reveal a consumer preference model.

\section{RESULTS AND DISCUSSION}

\section{Research results of AHP}

The study measure the C.I. and C.R. to resolute the answer steadiness. The result was over the limitation of C.R., and the questionnaire was viewed unavailable sample. Through the accounting of AHP, the weight and the importance are below as Table 2.

Overall, the forestry $(0.2125)$, the biodiversity $(0.1821)$ and the agriculture $(0.1050)$ are more relatively important, and the education (0.0066), transportation (0.0060), and cultural resource $(0.0056)$ are less relatively important.

\section{Research results of CVM}

The socio-demographic attribute was noteworthy that $66.43 \%(38.85 \%+27.58 \%)$ of the respondents were within the age range of 15-to-30, a latent future conservation source. Most of them were unmarried, educated at the college or junior-college level, students, or service-industry employees, and had an income level from none to US\$10,908 per year. T-testing on gender and marital status showed no significant difference in WTP. ANOVA on "Environmental satisfaction", "Environmental education", "Visiting Frequency", "Residential Area", "Educational", and "Occupation" showed no significant difference in WTP. "Age" and "Annual Income" showed no significant correlation between WTP and themselves.

A total of $10.79 \%$ (most satisfied) and $19.42 \%$ (satisfied) of the respondents listed their environmental satisfaction. In the "environmental education", $23.50 \%$ chose "related education background", $29.50 \%$ chose "Participation with the related courses", $16.79 \%$ chose "Media with environmental education", and $30.22 \%$ chose "not related background". In the "understanding of government policy", $38.85 \%$ said they have often listened the related policy descriptions, $23.26 \%$ said they have listened, $18.71 \%$ said they have some image to know that, $19.18 \%$ said they have no idea about that. 
TABLE 2. The accounting results of AHP

\begin{tabular}{|c|c|c|c|c|c|}
\hline $\mathbf{L V}$. & \multicolumn{2}{|l|}{ Main factors } & Weight & \multicolumn{2}{|c|}{ Importance } \\
\hline \multirow{3}{*}{ 芒 } & \multicolumn{2}{|c|}{ 1. Ecological steadiness } & 0.4367 & \multicolumn{2}{|c|}{1} \\
\hline & \multicolumn{2}{|c|}{ 2. Economic suitability } & 0.3660 & & 2 \\
\hline & \multicolumn{2}{|l|}{$\begin{array}{l}\text { 3. Social } \\
\text { acceptability }\end{array}$} & 0.2172 & \multicolumn{2}{|r|}{3} \\
\hline & LV.1 & factors & Weight & $\begin{array}{c}\text { Whole Weight } \\
\text { (Lv.1*Lv.2) }\end{array}$ & $\begin{array}{c}\text { Lv.2 } \\
\text { Importance }\end{array}$ \\
\hline \multirow{6}{*}{ בָ } & \multirow{2}{*}{\begin{tabular}{|l|}
$\begin{array}{l}\text { 1. Ecological } \\
\text { steadiness }\end{array}$ \\
\end{tabular}} & 1.1 Eco-resources & 0.5314 & 0.2621 & 1 \\
\hline & & 1.2 Human behaviors & 0.4686 & 0.2000 & 2 \\
\hline & \multirow{2}{*}{$\begin{array}{l}\text { 2. Economic } \\
\text { suitability }\end{array}$} & 2.1 Water quality & 0.5335 & 0.1988 & 3 \\
\hline & & 2.2 Water amount & 0.4665 & 0.1855 & 4 \\
\hline & \multirow{2}{*}{\begin{tabular}{|l|} 
3. Social \\
acceptability
\end{tabular}} & 3.1 Social economy & 0.4889 & 0.1127 & 5 \\
\hline & & 3.2 Local development & 0.5111 & 0.1060 & 6 \\
\hline & LV.2 & Sub-factors & Weight & $\begin{array}{c}\text { Whole Weight } \\
\text { (Lv.1*Lv.2*Lv.3) }\end{array}$ & $\begin{array}{c}\text { Lv.3 } \\
\text { Importance }\end{array}$ \\
\hline \multirow{17}{*}{$\stackrel{3}{3}$} & \multirow{3}{*}{ 1.1 Eco-resources } & 1.1.1 Forestry & 0.4259 & 0.2125 & 1 \\
\hline & & 1.1.2 Agriculture & 0.2104 & 0.1050 & 3 \\
\hline & & 1.1.3 Biodiversity & 0.3650 & 0.1821 & 2 \\
\hline & \multirow{2}{*}{$\begin{array}{l}1.2 \text { Human } \\
\text { behaviors }\end{array}$} & 1.2.1 Agriculture pollution & 0.5891 & 0.0736 & 6 \\
\hline & & 1.2.2 Recreation pollution & 0.4109 & 0.0514 & 7 \\
\hline & \multirow{2}{*}{ 2.1 Water quality } & 2.1.1 River pollution standard & 0.6889 & 0.0413 & 9 \\
\hline & & 2.1.2 Eutrophication & 0.3111 & 0.0187 & 12 \\
\hline & \multirow{2}{*}{ 2.2 Water amount } & 2.2.1 Acceptable capacity & 0.5333 & 0.0955 & 4 \\
\hline & & 2.2.2 Accumulation rate & 0.4667 & 0.0835 & 5 \\
\hline & \multirow{5}{*}{ 3.1 Social economy } & 3.1.1 Population & 0.2153 & 0.0073 & 14 \\
\hline & & 3.2.2 Transportation & 0.1756 & 0.0060 & 16 \\
\hline & & 3.3.3 Education and training & 0.1928 & 0.0066 & 15 \\
\hline & & 3.3.4 Land use & 0.2904 & 0.0099 & 13 \\
\hline & & 3.3.5 Cultural resources & 0.1660 & 0.0056 & 17 \\
\hline & \multirow{3}{*}{$\begin{array}{l}\text { 3.2 Local } \\
\text { development }\end{array}$} & 3.2.1 Public identification & 0.4181 & 0.0431 & 8 \\
\hline & & $\begin{array}{l}\text { 3.2.2 Main development } \\
\text { project }\end{array}$ & 0.3506 & 0.0361 & 10 \\
\hline & & 3.3.3 Local industry & 0.2775 & 0.0286 & 11 \\
\hline
\end{tabular}

(1) Lv.1 analysis

Based on the results, the ecological steadiness is the most important relatively (0.4367), the second is the economic suitability, and the least one is the social acceptability in the Level 1.

(2) Lv.2 analysis

In the Level 2, the eco-resource (0.5314)e is more relatively important than the human behaviors in the ecological steadiness; The water quality $(0.5335)$ and Social economy $(0.5766)$ is more relatively important in the economic suitability and social acceptability dividedly.

(3) Lv.3 analysis

In the eco-resources of the Level 3, the forestry is the highest (0.4259), and the agriculture is the lowest $(0.2104)$. For human behavior, the agriculture pollution $(0.5891)$ is more than recreational pollution (0.4109). Moreover, the River pollution standard is much more than the Eutrophication (0.3111) for the water quality, and the acceptable capacity $(0.5333)$ and accumulation rate are very similar 0.4667 for the water amount. Beside the land use (0.2904) and population (0.2153), others are similar as well. For the local development, the public identification (0.4181) plays an important role. 
Based on the WTP approach, the model of public preferences regarding sustainable Taiwan reservoir watershed is shown as below (with unstandardized coefficients):

$$
\begin{aligned}
& \mathrm{WTP}=2331.03+16.84 \text { (Environmental } \\
& \text { satisfactions) }+10.72 \text { (Environmental } \\
& \text { education standard) }+0.081 \text { (Income } \\
& \text { per year) }+10.24 \text { (Age) }
\end{aligned}
$$

The mean of the price that consumers are willing to pay (WTP) is NT 2755.544 per meal. For the expert results within the AHP questionnaires, they mention the mean per meal is NT 7655.3. Obviously, they have different identification for the issues, and other questions, especially environmental satisfaction, environmental protection and the potential value for the recent reservoir watershed have the same situation.

\section{CONCLUSIONS}

- For the AHP analysis, the ecological factors play significant role to influence the sustainability of Taiwan reservoir watershed, especially forestry, agriculture, and biodiversity. In addition, the human behavior is also relatively important to impact the ecological steadiness.

- In Taiwan, there are lots of the water resource problems, and it is very serious for the over capacity use of slope land. The management of the reservoir watershed is more important to overcome the problems of water issues, and the water amount is more than quality maintenance.

- For the social and economic factors, most of them are relatively lower than the physical factors. Comparison with the public and expert questionnaire result (CVM results), the identifications have big gap.

- Environmental policy cannot be away from public, and the public identification is more relatively important in social group. Therefore, how to make the partnership between public and governance is the key to joint conservation and benefit.

\section{REFERENCES}

CARSON R.T., MARTIN K., WRIGHT J., 1994: A bibliography of contingent valuation studies and papers. La Jolla, CA: Natural Resource Damage Assessment, Inc.

CIRIACY-WANTRUP S.V., 1947: Capital returns from soil-conservation practices. Journal of Farm Economics, 29, 1188-90.

CHANG I.S., YASUHIRO TSUJIMURA, MITSUO GEN, TATSUMI TOZAWA, 1995: "An Efficient Approach for Large Scale Project Planning Based on Fuzzy Delphi Method", Fuzzy Sets and Systems, 76, 277-288.

HANEMANN W.M., 1994: Valuing the environment through contingent valuation. The Journal of Economic Perspectives, 8(4), 19-43.

MILLET I., HARKER P.T., 1990: "Globally Effective Questioning In the Analytic Hierarchy Process", European Journal of Operational Research, Vol. 48, pp. 88-97.

PORTNEY P.R., 1994: The contingent valuation debate: Why economists should care. The Journal of Economic Perspectives, 8(4), 3-17.

SCHELLING T., 1968: The life you save may be your own, In Chase S. (Ed.), Problems in public expenditure analysis (pp. 143-144). Washington D.C.: Brooklings Institution.

Streszczenie: Badania struktury zrównoważonej gospodarki oraz ocena wartości ekonomicznej zlewni zbiorników wodnych na Tajwanie. W pracy przedstawiono wyniki badań przeprowadzonych dla określenia hierarchii ważności czynników ekologicznych, ekonomicznych i socjalnych związanych ze zrównoważonym zagospodarowaniem zlewni zbiorników wodnych na Tajwanie. W badaniach zastosowano metodę ankietową, w której 
respondenci stosując pięciostopniową skalę mieli wskazać ważność 22 określonych przez ekspertów czynników związanych $\mathrm{z}$ ochroną i zrównoważonym korzystaniem $\mathrm{z}$ zasobów środowiska, wpływających na standard życia mieszkańców oraz możliwości rozwoju gospodarczego na obszarze zlewni zbiorników wodnych. Stwierdzono, że najważniejsze znaczenie dla ludności mają czynniki ekologiczne, w szczególności zapewnienie stabilności przyrodniczej poprzez zachowanie bioróżnorodności oraz ochrony zasobów naturalnych, w tym ilości retencjonowanej wody.

MS. received April 2010
Authors' addresses:

\section{Shih-Chung Lu}

National Taiwan University

71 Chau-Shan Rol.

106 Taipei

Taiwan

e-mail: shihchunglu@gmail.com

\section{Szu-Hsien Peng}

Department of Architecture and Interior Design Chienkuo Technology University

Taiwan

\section{Hwong-Wen Ma}

Graduate Institute of Environmental Engineering National Taiwan University

Taiwan 